\title{
SOCIAL RESPONSIBILITY ASSESSMENT OF COOPERATIVE ORGANIZATIONS IN TERTIARY EDUCATIONAL INSTITUTIONS IN KADUNA STATE, NIGERIA
}

\author{
Charles Uchenna Onugu \\ Nnamdi Azikiwe University, Awka \\ Usman A. Usman \\ Nnamdi Azikiwe University, Awka
}

\&

Nwamaka Chinyere Moore

Nnamdi Azikiwe University, Awka

\begin{abstract}
This study focused on assessing the social responsibility of cooperative organizations resident in tertiary institutions in Kaduna State, Nigeria. The population of the study was one thousand four hundred and twelve $(1,412)$ registered members of cooperative organizations resident in tertiary institutions in Kaduna State. Using Taro Yamane's formula with allowable error e= 0.05, a sample size of three hundred and twelve (312) was used. This sample was distributed equally (at fifty-two each) among the six cooperative organizations that were selected one from each of the six tertiary institutions; the six tertiary institutions were judgmentally selected two from each senatorial zone in the State. A 5point Likert-scale measure was used. The data collected were analyzed using descriptive statistics (percentage, mean Likert-scale) and inferential statistics (Spearman rho test). The results of the study revealed as follows: The only significant social responsibility activity carried out by cooperative organizations resident in tertiary institutions in the State was to help their host communities in providing physical infrastructural facilities $(x=3.02)$. Thus, the cooperative organizations have not met their social responsibilities to their host communities $(P$-value $=2.781 ; r$-cal $=1.517)$. However, the little they have been able to do has had a positive and significant effect $(P$-value $=0.752$; $r$-cal $=3.439)$. There are many challenges impeding the provision of social responsibility activities by these cooperative organizations; the major challenges include lack of fund, poor relationship with host communities, and hostile attitude of the host communities. The study therefore recommended that cooperative organizations in tertiary institutions in Kaduna State should strive to imbibe the culture of concern for host community as a cardinal cooperative principle.
\end{abstract}

Keywords: Social Responsibility, Cooperative organizations, Tertiary Educational Institutions.

\section{Introduction}

Cooperative organizations are business enterprises with a dual objective of promoting the social and economic well-being of its members. In contemporary human society, there is interdependence among many groups, and the social environment of cooperative business has widened. Consequently, cooperative organizations have to be concerned about their social responsiveness to the environment in which they operate. As a business, cooperatives should consider the social implications of their decisions and activities on the host community (Karthikeyan, 2012). 
In recognizing the relevance of a cordial relationship between cooperative societies and the host community, the International Cooperative Alliance (I.C.A.) in its statement on cooperative identity adopted in 1995 general assembly held in Manchester on the occasion of the Alliance Centenary, included, among others, the cooperative values. These values, numbering nine, include social responsibility grouped under moral behavior. The value of social responsibility maintains that cooperatives should aspire to maintain sustainable human development. It further states that people should form or join cooperatives in order to take up responsibility both for themselves and their host community (Amahalu, 2006).

According to Barnett (2007), social responsibility is a form of corporate investment characterized by a dual orientation towards the improvement of social welfare and stakeholder relations. This stakeholder relation explains why employees, as a stakeholder group, exert influence on corporate social responsibility (CSR) policy. Cooperatives can act as agents for social change when they promote socially responsible behavior. Ajayi (2016) observed that the need for social responsibility includes peaceful cooperation between organizations and host communities, elimination of distrust or disharmony, and development. It is also for promoting stability in the society (Gambo, 2016). The significance of social responsibility is vividly recognized in its cooperative principle of "Concern for the Community."

Although factors like funding, mismanagement, poor leadership, strife, misunderstanding etc could hinder cooperative societies from performing their social responsibility, it is mandatory for social responsibility to be regular and targeted at tangible projects that could contribute meaningfully to the socio-economic lives of the members of the immediate community (see Obodoechi, 2002; Ismail, 2009; Igwe, 2011; Praveenya, 2015).

Unfortunately, cooperative organizations tend to strive more to satisfy their members' needs, giving little or no attention to the social responsibility they ought to perform as a statutory practice of modern corporation. Gambo (2016) argued that most cooperative societies either do not perform their social responsibility at all or they do it haphazardly. Arguably, it appears that they are rather so much concerned about the welfare of their members that the issue of social welfare of their host community appears to be neglected, thus, creating distrust, disharmony, and possible confrontation by their host communities.

Unarguably, situation and activities of tertiary educational institutions have some negative operational impact on their host communities which demand some level of social responsiveness on their part as a way of cushioning some of the effects. Some of these negative impacts include the fact that these host communities may have to live with increase in crime rates and cultism, compulsory acquisition of their land without adequate compensation and increase in the cost of living due to higher demand pull. There are also the gradual, but sustained erosion of highly cherished community social values and culture and the continuous threat to community security, amongst others (Igbinedion \& Ovbiagele, 2012).

Increasingly, communities are getting aware of their rights and are demanding that corporate bodies operating in their domains meet their social responsibilities to them which could be in form of employment of their qualified children, admission quota, award of contracts, financial donations, or projects (infrastructural) execution, etc. There is paucity of research on the activities of cooperative organizations in Kaduna State, Nigeria especially in the discharge of social responsibility to their host communities. 
The broad objective of this study was to assess the provision of social responsibility by cooperative organizations in tertiary institutions in Kaduna State. The specific objectives are to: (1) Identify social responsibility activities carried out by cooperative organizations of tertiary institutions in Kaduna State to their host communities. (2) Determine the effect of social responsibility activities of cooperative organizations on their host communities. (3) Identify the challenges faced by cooperative societies of tertiary institutions in Kaduna state in the discharge of their social responsibility mandate to their host communities.

In order to achieve these set objectives, the following null hypotheses were proposed and tested: $\mathrm{H}_{01}$ : Cooperative societies of tertiary educational institutions of Kaduna State do not carry out social responsibility activities sufficiently in their host communities. $\mathrm{H}_{02}$ : There is no significant positive effect of social responsibility activities by cooperative societies of Kaduna State tertiary educational institutions on their host communities.

\section{Methodology}

Kaduna State is in North-West Nigeria and its capital is Kaduna. According to the National Population Census of 2006, Kaduna State has a population of 6,066,562, and lies on Longitude and Latitude of $7^{\circ} 45^{\prime} \mathrm{E}$ and $10^{\circ} 20^{\prime} \mathrm{N}$ respectively. The State comprises different ethnic groups and the predominant language is Hausa. Residents of the State are mainly farmers, artisans, entrepreneurs and civil servants. Kaduna is one of the education centres in Nigeria, with many colleges and recognized universities notably, the Nigerian Defence Academy; Ahmadu Bello University, Zaria; Nuhu Bamalli Polytechnic, Zaria; Kaduna State University; Federal Polytechnic, Kaduna; Nigerian College of Aviation Technology, Zaria; College of Education, Gidan Waya, Kafanchan; Shehu Idris College of Health Sciences and Technology, Makarfi; School of Nursing-Makarfi; Institute of Leather Research-Zaria; Federal College of EducationZaria; National Open University of Nigeria; National Water Resources Institute, Kaduna; Nigerian Institute of Transport Technology, Zaria; National Teachers Institute, Kaduna and School of Midwifery, Kafanchan (Wikipedia, 2016). These schools have different cooperative societies.

\section{Population of the Study}

The population of this study was 1,412 registered members of twelve co-operative organizations in tertiary institutions of Kaduna State. This was obtained from data provided by the Kaduna State Register of Cooperatives and the various cooperative organizations (see Table 1 for the population distribution). 
Table 1: Cooperative Organizations in Tertiary Institutions in Kaduna State and their Membership strength.

\begin{tabular}{|c|c|c|}
\hline $\mathrm{S} / \mathrm{N}$ & COOPERATIVE SOCIETIES & MEMBERSHIP STRENGTH \\
\hline & College of Admin/Business Studies Coop. & \\
\hline & Investment \& Credit Society Ltd. & 263 \\
\hline \multicolumn{3}{|c|}{ 2. Central Admin Investment/Credit } \\
\hline & Cooperative Society Ltd. & 102 \\
\hline 3. & Trust Multipurpose Cooperative Society Ltd. & 99 \\
\hline & College of Environment Studies Investment \& & 88 \\
\hline & Credit Cooperative Society Ltd. & \\
\hline & College of Admin studies \& Social Science & \\
\hline & Investment Cooperative Society Ltd. & 114 \\
\hline & ABU Staff Cooperative Society Ltd. & 160 \\
\hline & NuBa. Staff Muti-purpose Cooperative Society & 103 \\
\hline & KPT/KAP Staff Cooperative Society & 100 \\
\hline & KASU Staff Muti-purpose Cooperative & 108 \\
\hline 10. & KADSCOE Staff Investment Cooperative Society & 104 \\
\hline 11. & SOMID Staff Cooperative Society & 96 \\
\hline & School of Nursing (SON) Staff Thrift Cooperative & 75 \\
\hline & TOTAL & 1,412 \\
\hline
\end{tabular}

Source: Kaduna State Register of Cooperative Societies (2016)

\section{Sampling Procedure}

The study employed multi-stage sampling procedure in the selection of the sample size. In the first stage, Kaduna State was divided into its three senatorial zones, which are Kaduna North, Kaduna Central and Kaduna South. In the second stage, a sub sampling also called a two-stage sampling, was used to judgmentally select two tertiary institutions from each of the senatorial zones: giving a total of six institutions. The selected tertiary institutions were Nuhu Barnalli Polytechnic, Zaria; School of Nursing-Makarfi; Federal Polytechnic, Kaduna; Kaduna State University, Kaduna; College of Education GidanWaya and School of Midwifery, Kafanchan. In the third stage, one cooperative society was selected from each of the six schools and they were NuBa Staff Multi-purpose Cooperative Society; School of Nursing (SON) Staff Thrift Cooperative; KPT/KAP Staff Cooperative Society; KASU Staff Multi-purpose Cooperative Society, and SOMID Staff Cooperative Society. Lastly, in the fourth stage, the sample size was divided equally among the six selected cooperative societies which gave fifty-two (52) for each. Overall, the sample for this study was three hundred and twelve (312) cooperative society members of tertiary institutions in Kaduna State. This was statistically determined from the population of study using Taro Yamane (1967) formula.

\section{Collection of Data}

Primary and secondary sources of data were used to collect data for this study. The primary source was based on questionnaire and it was the major source of data generation. The secondary sources were textbooks, journals, internet and publications on cooperative societies of tertiary institutions. For the administration of the questionnaire, three research assistants who were trained on the specific objectives and essence of the investigation were used. The training was geared towards their in-depth understanding of the content of the instrument and the method of administration and collection. This enabled them to effectively assist the researchers in administering the questionnaire and retrieving them for collation. The 
respondents, who could not fill and return their own copies of the questionnaire at the point of administration were given seven days to do so. Within this period, the researchers and their assistants kept their telephone lines of communication with the respondents open for possible inquiries. After the seven days, the researchers and their assistants went back and retrieved the questionnaires for analysis. After collation, it was discovered that thirty-one (31), out of the three hundred and twelve (312) copies of the questionnaire administered, were either not properly filled or misplaced by the respondents. Hence, two hundred and eighty-one (281) validly completed and returned copies of the questionnaire, representing a $90 \%$ return rate, were used for data analysis.

Data was analyzed using the Statistical Package for Social Sciences (SPSS). The personal characteristics of the respondents were descriptively analyzed using frequency, percentages and means. A 5-point Likert-scale measure was first used to structure the questionnaire used in collecting data for the analysis of the specific objectives as well as testing the null hypotheses set. The following decision rules guided the analysis.

- For specific objective 1, any social responsibility activity with mean rating of 3.0 and above was adjudged to have been carried out by cooperative societies of tertiary institutions of Kaduna State to their host communities, while those below 3.0 were not carried out.

- For specific objective 2, any of the social responsibility index with mean rating of 3.0 and above was adjudged to be positive while those below were adjudged to be negatively impacted on their host communities.

- For specific objective 3, any factor with mean rating of 3.0 and above was rated as influential to the provision of social responsibility by cooperative organizations of tertiary institutions of Kaduna State to their host communities, while those below 3.0 were rated non- influential to the provision of social responsibility by the cooperative societies.

- Any challenge with mean rating of 3.0 and above was rated as a constraint (problem) in the application of the social responsibility mandate by cooperative societies of tertiary institutions of Kaduna State to their host communities, while those below that were not considered a problem.

The study hypotheses $\left(\mathrm{H}_{1}-\mathrm{HO}_{2}\right)$ were tested using Pearson Product Moment Correlation analysis. The choice of this tool is because it indicates the strength, direction and significance of bivariate relationships among variables that were measured at interval or ratio level. The decision was to reject the null hypothesis and accept the alternate if the r-calculated was greater than the p-value.

The formulated model for Moment Correlation is:

$$
\begin{array}{ll}
\mathrm{r}=\sum_{j=1}^{n} x_{j}=x_{1}+x_{2}+\cdots+x_{n} ; & \mathrm{p}=\sum_{j=1}^{n} a_{j}=a_{1}+a_{2}+\cdots+a_{n} \\
\text { where } \mathrm{r}=\text { Correlation Coefficient; } & \mathrm{p}=\mathrm{p} \text {-value or significance level; } \\
x_{j}(\mathrm{j}=1, \ldots, \mathrm{n}) \text { are the variables; } & \mathrm{a}_{\mathrm{j}}=\operatorname{sign}\left(\mathrm{a}_{\mathrm{j}}\right)=\text { sign of } \mathrm{a}_{\mathrm{j}} ;(\mathrm{j}=1, \ldots, \mathrm{n})
\end{array}
$$

\section{Results and Discussions}

\section{Personal Characteristics of the Respondents}

The socio-demographic characteristics of the respondents were presented on Table 2. Majority (143 or $50.9 \%$ ) of the respondents fell within the 41 to 51 years range; their mean age was 
43years. Also, majority (149 or 53.0\%) were females, while $132(47.0 \%)$ were males. The highest educational level of many (110 or $39.1 \%$ ) was HND/B.Sc., implying they were learned and knowledgeable. From the Table also, it could be deduced that most $161(57.2 \%)$ of the study participants under study were married and that the dominant religious affiliation of the respondents was Islam 187 (66.6\%). Lastly, of the respondents 196(69.7\%) had about 6-10 years cooperative experience, with a mean of 8 years. This implies that they were experienced in cooperative experience and the essence of working together for the accomplishment of a task. This aligns itself with the finding of Ibrahim (2001) that human society recognized the advantages of providing individual and group needs collectively.

Table 2: Distribution of Respondents by Personal Characteristics

\begin{tabular}{|c|c|c|c|}
\hline Variables & $\mathrm{N}=\mathbf{2 8 1}$ & $\%$ & $(\mathbf{x})$ \\
\hline \multicolumn{4}{|l|}{ Age (years) } \\
\hline $19-29$ & 8 & 2.8 & \\
\hline $30-40$ & 56 & 20.0 & \\
\hline $41-51$ & 143 & 50.9 & 43 \\
\hline $52 \&$ Above & 74 & 26.3 & \\
\hline \multicolumn{4}{|l|}{ Gender } \\
\hline Male & 132 & 47.0 & \\
\hline Female & 149 & 53.0 & \\
\hline \multicolumn{4}{|l|}{ Educational qualification } \\
\hline FSLC & 6 & 2.1 & \\
\hline WAEC/GCE & 47 & 17.0 & \\
\hline $\mathrm{OND} / \mathrm{NCE}$ & 83 & 29.5 & \\
\hline HND/B.sc & 110 & 39.1 & \\
\hline M.Sc/Ph.D. & 35 & 12.4 & \\
\hline \multicolumn{4}{|l|}{ Marital Status } \\
\hline Single & 27 & 10.0 & \\
\hline Married & 161 & 57.2 & \\
\hline Widowed & 91 & 32.3 & \\
\hline Divorced /separated & 2 & 0.7 & \\
\hline \multicolumn{4}{|l|}{ Religion } \\
\hline Islam & 187 & 66.6 & \\
\hline Christianity & 94 & 33.4 & \\
\hline Traditional African Religion & - & - & \\
\hline \multicolumn{4}{|c|}{ Cooperative Membership (years) } \\
\hline Less than 5 years & 42 & 15.0 & \\
\hline $6-10$ & 196 & 69.7 & 8.3 \\
\hline $11-15$ & 26 & 9.2 & \\
\hline $16 \&$ Above & 17 & 6.0 & \\
\hline
\end{tabular}

Source: Field Survey 2016

\section{Social Responsibility Activities in Host Communities}

Table 3 shows the social responsibility activities carried out by cooperative organizations of tertiary institutions in Kaduna State in their host communities. It can be seen that, from all the social responsibility activities available, the notable activity embarked upon by tertiary institutions in their host communities was helping them in providing some physical infrastructural facilities $(\mathrm{x}=3.02)$. This finding corroborates that of Igbinedion \& Ovbiagele (2012) that tertiary educational institutions in Delta State were engaged in the development of physical infrastructures. However, it can be said that the cooperative organizations in Kaduna 
State tertiary institutions have not really lived up to their expectations, hence the need for them to look inwards and see how to step up and assist their host communities in order to promote peaceful co-existence and cordial relationship.

Table 3: Distribution of Respondents on the Social Responsibility activities carried out by the Cooperative Organizations.

\begin{tabular}{|lcc|}
\hline S/N Social Responsibility Activities & $\mathbf{n = 2 8 1 ( \mathbf { x } )}$ & Remarks \\
\hline 1. Control and regulate environmental pollution & $21(7.5 \%)$ & 2.46 Not carried out \\
2. Make donations for charity purposes. & $35(12.5 \%)$ & 2.71 Not carried out \\
3. Make donations for social purposes. & $25(8.9 \%)$ & 2.12 Not carried out \\
4. Use their net surplus to address some community problems & $32(11.4 \%)$ & 2.50 Not carried out \\
5. Help their host communities in providing physical infrastructural & & \\
& $58(20.6 \%)$ & 3.02 Carried out \\
6. Contilies & $31 .(11.0 \%)$ & 2.18 Not carried out \\
7. Employ qualified immediate members of their host communities & $36(12.8 \%)$ & 2.90 Not carried out \\
8. Provide Health care services & $9(3.2 \%)$ & 1.43 Not carried out \\
9. Create/promote cultural awareness in their host communities & $23(8.2 \%)$ & 2.00 Not carried out \\
10. Give out soft loans out & $15(5.34 \%)$ & 1.65 Not carried \\
\hline
\end{tabular}

\section{Source: Field Survey, 2016}

\section{Testing the Hypothesis}

Hypothesis One (H01): Cooperative organizations of tertiary educational institutions of Kaduna State do not carry out social responsibility activities sufficiently in their host communities.

Examination of the coefficient revealed that only "helping their host communities in providing some physical infrastructural facilities" was a significant factor, and all others were not significant at 5\% level of significance. As the calculated P-Value (2.781) was greater than rcal (1.517); the null hypothesis was upheld and the study concludes that cooperative organizations of tertiary educational institutions of Kaduna failed to meet their expectations in carrying out their social responsibility to their host communities. 
Table 4: Test of Hypothesis One

\begin{tabular}{|c|c|c|c|}
\hline \multicolumn{3}{|c|}{ Social Responsibility Activities } & Correlations $^{\mathbf{b}}$ \\
\hline \multirow{12}{*}{$\begin{array}{l}\text { Sperman's } \\
\text { rho }\end{array}$} & $\begin{array}{l}\text { Control and regulate environmental } \\
\text { pollution in Kaduna State }\end{array}$ & $\begin{array}{l}\text { Correlation Coefficient } \\
\text { Sig. ( } 2 \text { tailed) }\end{array}$ & 1000 \\
\hline & Make donations to charity in Kaduna & Correlation Coefficient & -099 \\
\hline & State & Sig. (2 tailed) & .394 \\
\hline & Make donation for social purpose in & Correlation Coefficient & .029 \\
\hline & Kaduna State & Sig. (2 tailed) & .802 \\
\hline & Use their next surplus to address some & Correlation Coefficient & -079 \\
\hline & problems of Kaduna State communities & Sig. (2 tailed) & -085 \\
\hline & $\begin{array}{l}\text { Help their host communities in } \\
\text { providing some physical infrastructural } \\
\text { facilities }\end{array}$ & $\begin{array}{l}\text { Correlation Coefficient } \\
\text { Sig. ( } 2 \text { tailed })\end{array}$ & .064 \\
\hline & Contribute to the educational needs of & Coefficient & .202 \\
\hline & their host communities & Sig. (2 tailed) & .180 \\
\hline & Employ qualified immediate member of & Correlation Coefficient & .023 \\
\hline & their host communities & Sig. (2 tailed) & .844 \\
\hline
\end{tabular}

*Correlation at the 0.05 level (2-tailed). b. Listwise $\mathrm{N}=76$

$\mathrm{r}=1.000+0.099+0.029+0.079+0.085+0.202+0.023=1.517$

$\mathrm{P}$-value $=0.394+0.802+0.497+0.064+0.180+0.844=2.781$

\section{Effects of the discharge of SR by the COs on their Host Communities}

The effects of the discharge of social responsibility by cooperative organizations of tertiary institutions in Kaduna State to their host communities were assessed by the members of the organizations A cursory look at Table 5 shows that the discharge of social responsibility by cooperative organizations of tertiary institutions in Kaduna State to their host communities has to a reasonable extent, impacted positively on their host communities. It can be deduced that it creates a favourable attitude from their host communities towards cooperative ventures of the institutions with mean rate $x=3.61$. Also, it enhances confidence and love for the existing cooperative organisations $(\mathrm{x}=4.06)$, as well as make up for social services not readily provided by the government $(x=3.35)$. Lastly, the application of social responsibility by cooperative organizations of tertiary institutions in Kaduna State helps to remove distrust and encourages involvement in the cooperative organizations $(x=3.55)$. This agrees with the findings of Asogwa \& Onuh (2014) that Kogi State University (KSU) cooperative organization has played a considerable role in providing its social responsibility activities to its host communities thereby impacting on them. 
Table 5: Distribution of Respondents on the Perceived Effect of the Application of Social Responsibility by the Cooperative Organizations

\begin{tabular}{|c|c|c|c|}
\hline S/N Effect of the Application of Social responsibility & $\mathrm{n}=\mathbf{2 8 1}$ & $(\mathbf{x})$ & Remark \\
\hline $\begin{array}{l}\text { 1. Creates favourable attitude towards the cooperative } \\
\text { ventures }\end{array}$ & $52(18.5 \%)$ & 3.61 & Positive \\
\hline $\begin{array}{l}\text { 2. Enhances confidence and love for the cooperative } \\
\text { ventures }\end{array}$ & $100(35.6 \%)$ & 4.04 & Positive \\
\hline $\begin{array}{l}\text { 3. Makes up for social service not readily provided } \\
\text { by the government }\end{array}$ & $44(15.7 \%)$ & 3.35 & Positive \\
\hline 4. Help Kaduna State communities to wear new look & $13(4.6 \%)$ & 2.11 & Negative \\
\hline nmunities environmentally safe & $7(2.5 \%)$ & 1.89 & Negative \\
\hline 6. Makes the communities socio-economically stable & $16(5.7 \%)$ & 2.38 & Negative \\
\hline $\begin{array}{l}\text { 7. Removes distrust and encourages involvement in } \\
\text { 8. cooperativeorganisations }\end{array}$ & $49(17.4 \%)$ & 3.55 & Positive \\
\hline
\end{tabular}

Source: Field Survey, 2016

\section{Hypothesis Two $\left(\mathrm{H}_{02}\right)$}

There is no significant positive effect of social responsibility activities of cooperative organizations of Kaduna State tertiary educational institutions on their host communities. An examination of the coefficient revealed that other variables were significant except "helps Kaduna communities to wear a new look" (0.523); makes Kaduna communities be environmentally safe (0.144); and makes Kaduna communities socio-economically stable $(0.113)$ which were not significant at $5 \%$ of level of significance. Since the calculated P-value (0.752) is less than the r-cal (3.439) the null hypothesis was rejected and alternate accepted; implying that there is a significant positive effect of social responsibility activities of cooperative societies of Kaduna State tertiary educational institutions to their host communities.

Table 6: Test of Hypothesis Two

\begin{tabular}{|c|c|c|c|}
\hline \multicolumn{3}{|c|}{ Social Responsibility Activities } & Correlations $^{b}$ \\
\hline \multirow{14}{*}{$\begin{array}{l}\text { Sperman's } \\
\text { rho }\end{array}$} & Control and regulate environmental & Correlation Coefficient & 1000 \\
\hline & pollution in Kaduna State & Sig. (2 tailed) & \\
\hline & Make donations to charity in Kaduna & Correlation Coefficient & -099 \\
\hline & State & Sig. (2 tailed) & .394 \\
\hline & Make donation for social purpose in & Correlation Coefficient & .029 \\
\hline & Kaduna State & Sig. (2 tailed) & .802 \\
\hline & Use their next surplus to address some & Correlation Coefficient & -079 \\
\hline & problems of Kaduna State communities & Sig. (2 tailed) & -085 \\
\hline & Help their host communities in & Correlation Coefficient & \\
\hline & $\begin{array}{l}\text { providing some physical infrastructural } \\
\text { facilities }\end{array}$ & Sig. (2 tailed) & .064 \\
\hline & Contribute to the educational needs of & Correlation Coefficient & .202 \\
\hline & their host communities & Sig. (2 tailed) & .180 \\
\hline & Employ qualified immediate member of & Correlation Coefficient & .023 \\
\hline & their host comm & Sig. (2 tailed) & .844 \\
\hline
\end{tabular}


*Correlation is significant at the 0.05 level (2-tailed). b. Listwise $\mathrm{N}=76$

$\mathrm{r}=2.010+.102+.126+-011+-267+-267+.704+.219=3.439$

p-value: $=003+.010+.092+.103+.44+.103+.001=0.752$

\section{Challenges faced by the COs in carrying out SR mandate to Host Communities}

The challenges constraining the cooperative organizations of tertiary institutions of Kaduna State in carrying out the social responsibility mandate to their host communities are presented in Table 7 where notable challenges (problems) included unavailability of fund $(x=4.25)$; Poor mutual relationship between cooperative societies and their host communities $(x=4.08)$; Youth restiveness ( $\mathrm{x}=4.34)$; Poor administration (Leadership) $(\mathrm{x}=3.02)$; Delay in release of funds/subventions by the government to tertiary institutions $(x=4.16)$; Inter-community agitations and strife $(x=4.51)$; hostile attitude of the host communities $(x=4.09)$; lack of poor operational guidelines $(x=4.42)$; unaccountability of office $(x=3.86)$, and greedy or self-centred community leadership ( $\mathrm{x}=4.00)$. These finding substantiate that of Abu and Audu (2016), Igbinedion and Ovbiagele (2012) who separately found that inadequate funding, agitations and strife were the major problems constituting tertiary institutions in Kogi and Delta States respectively from carrying out their social responsibilities to their host communities.

\section{Table 7: Respondents Views on Challenges faced by the COs in Discharging SR}

\begin{tabular}{|c|c|c|c|c|}
\hline $\mathbf{S} / \mathbf{N}$ & Challenges & $n=281$ & $(\mathbf{x})$ & Remark \\
\hline 1. & Inadequate fund & $38(13.5 \%)$ & 4.25 & lenge \\
\hline 2. & $\begin{array}{l}\text { Poor mutual relationship between cooperatives } \\
\text { and host communities }\end{array}$ & $22(7.8 \%)$ & 4.08 & llenge \\
\hline 3. & Youth restiveness & 40( & 4.34 & cha \\
\hline 4. & ion (Leadership) & 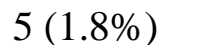 & 3.02 & nge \\
\hline 5. & $\begin{array}{l}\text { Delay in release of funds/subventions by the } \\
\text { government }\end{array}$ & $32(11.4 \%)$ & 4.16 & nge \\
\hline 6. & . $\quad . \quad$. & & 4.5 & \\
\hline 7. & Hos & 27 & 4.09 & enge \\
\hline 8. & ration guidelines & $43(15.3 \%)$ & 4.42 & llenge \\
\hline 9. & Unc & 10( & 3.86 & enge \\
\hline 10. & Greedy or self-centred community leadership & $18(6.4 \%)$ & 4.00 & challenge \\
\hline
\end{tabular}

Source: Field Survey, 2016

\section{Conclusions}

The personal profile of the members of cooperative organizations in tertiary institutions in Kaduna State vividly showed members at an average productive age of 43 years. They were also learned as most of them had either OND or degree certificate with an average of 8 years' experience in cooperative association. Though the study showed that the cooperative organizations were inactive in providing social responsibility activities to their host communities, the members however opined that the much they provided had impact on their host communities. There were many challenges impeding the provision of social responsibility activities by cooperative organizations to their host communities in tertiary institutions in Kaduna State. The challenges were mostly on lack of funds, poor relationship between cooperatives and the host communities, hostile attitude of the host communities, etc.

It is important that cooperative organizations imbibe seriously the act of making impact within their host communities through provision of social responsibility activities. In doing so, they will put into practice one of the key cooperative principles concern for the community. 
Therefore, efforts must be made by cooperative organizations in tertiary institutions in Kaduna State to comply with this principle by improving their operations through at least five means. The first is making greater efforts to increase their membership so as to internally have the capacity to raise more funds. The second involves reaching out to donor agencies, both within and outside Nigeria to raise more funds for their members and their organizations to expand their operations and have the enhanced capacity to provide social responsibility activities to their host communities. The third entails, ensuring sustained training of their members to imbibe the culture and practice of "care for their host community", as enshrined in the cooperative principle through social responsibility activities. The fourth means having a strong leadership and management that has the vision and capacity to move the cooperative organizations to great heights. The fifth requires having a good leadership that can mutually relate with the host community and as well have the capacity and will to manage conflicts when they arise.

\section{References}

Abu, K. M. \& Audu, S. J. (2Q16). Corporate social responsibility in Nigeria tertiary institutions: An empirical assessment. International Journal of Capacity Building in Education \& Management, 2(4), 25-35.

Ajayi, A. (2016). The influence of corporate social responsibility on profit after tax of some selected deposit money banks in Nigeria. Journal of Educational Research, 4 (10).

Amahalu, C.A. (2006). Cooperative impact on host communities. Journal of Management, 12(1), 201-211.

Asogwa, C. E., \& Onuh, J. Y. (2014). Corporate social responsibility in higher institutions: A study of Kogi State University, Anyangba. International Journal of African \& Asian Studies, 4(1), 32-42.

Barnett, M. L. (2007). Stakeholder influence capacity and the variability of financial returns to corporate social responsibility. Journal of Academy of Management, 32(3), 794-816.

Gambo, N. (2016). Contributions of corporate social responsibility to agricultural development in Nigeria. Journal of Sustainable Development in Africa, 13(3).

I.C.A. (1995). Cooperative: The bane for sustainable development of Communities. I.C.A Working Paper.

Igbinedion, V.I., \& Ovbiagele, A.O. (2012). Corporate social responsibilities of tertiary educational institutions to host communities in Delta South Senatorial District of Delta State of Nigeria. International Review of Social Sciences \& Humanities, 4 (1), 133-141.

Igwe, S.R. (2011) (Ed.). Corporate social responsibility. Port-Harcourt: AELI Publishers.

Ismail, M. (2009). Corporate social responsibility and its role in community development: An international perspective. Journal of International Social Research, 2(9), 199-209.

Karthikeyan, C. (2012). Cooperatives and social implications. International Journal of Business Ethics, 31(2), 121-129.

Obodoechi, C. (2002). Social responsibilities of cooperatives to host communities. International Journal of Economics, 3(1), 17-22.

Praveenya, J. (2015). The need for social responsibility of business enterprises. Business Management Online Journal.

Uzoka, N. D. \& Eze, O. R. (2015). Effect of corporate social responsibilities of corporate institutions on their host communities: A case of Ebonyi State University and Zenith Bank Pic. International Journal of Economic Development Research \& Investment, 6(2), 26-3. 